\title{
Evaluation of maxillary sinus anatomical variations and pathologies in elderly, young, posterior dentate and edentulous patient groups with cone-beam computed tomography
}

\author{
N. Dedeoğlu, O. Altun \\ Inonu University, Faculty of Dentistry, Department of Oral and Maxillofacial Radiology, Malatya, Turkey
}

[Received: 9 November 2018; Accepted: 23 January 2019]

\begin{abstract}
Background: The aim of this study was to evaluate the frequency of maxillary sinus pathologies and anatomic variations in elderly and edentulous patients by using cone-beam computed tomography (CBCT).

Materials and methods: The study included elderly and young patient groups. The elderly group involved posterior edentulous and dentate patients. CBCT images were assessed, and the presence of any pathological findings, septa, accessory maxillary ostium, and Haller cell in each maxillary sinus were recorded according to the groups. Chi-square test was used to analyse the intergroup differences $(p<0.05)$.
\end{abstract}

Results: There was no statistically difference between the young and elderly groups regarding the presence of a pathology $(p=0.077)$ and septa $(p=0.37)$, whereas accessory ostium ( $p=0.009)$ was more common and Haller cell $(p=0.000$ ) was less common in the elderly group when compared to the young group. There was no significant difference between the edentulous and dentate group regarding the presence of a pathology $(p=0.39)$, septation $(p=0.69)$ and Haller cell ( $p=0.75)$; accessory ostium rate was found to be increased $(p=0,015)$ in edentulous patients.

Conclusions: It was observed that the frequency of accessory maxillary ostium was increased in elderly, especially in edentulism. And the frequency of Haller cell was found to be decreased in elderly patients. (Folia Morphol 2019; 78, 3: 595-599)

Key words: elderly, edentulous, maxillary sinus, accessory ostium, Haller cell

\section{INTRODUCTION}

The operations performed to provide bone support to dental implants in the atrophic maxilla are known as sinus lifting and augmentation; they have a high success rate $[4,19]$. Assessing the maxillary sinus anatomy by using cone-beam computed tomography (CBCT) prior to sinus lift surgery performed for posterior implants is recommended, in general [13]. The presence of maxillary sinus pathologies and septa require extra carefulness in dental implant procedures [10]. It is known that some anatomical variations of paranasal sinus can cause a tendency to infections while others can cause surgical complications [2, 3]. It was reported that variations of the maxillary sinus such as accessory maxillary ostium and Haller cell could lead to sinusitis $[2,22]$.

Today, the rate of dental implant applications is increasing. Since this need is particularly increased 
in posterior edentulous and elderly patients, dentists should be well educated about pathologies, and variations of the maxillary sinus.

This study aims to compare statistically the frequencies of maxillary sinus pathologies and anatomical variations such as septa, accessory maxillary ostium, and Haller cells in young and elderly patients, posterior dentate and edentulous patients in elderly patients whom CBCT images were obtained before.

\section{MATERIALS AND METHODS}

The study was conducted by the retrospective analysis of patients CBCT results, who had been admitted to Inonu University Faculty of Dentistry, Department of Oral and Maxillofacial Radiology between years of 2011 and 2017 for various reasons (preoperative evaluations for planned implant procedures or other operations, orthodontic assessments, etc.).

\section{Study samples}

An ethics committee report was obtained for this retrospective study from the Inonu University Medical Sciences Scientific Research and Publication Ethics Committee (2017/24-15).

Two hundred and fifty-eight maxillary sinus CBCT images from 140 patients were evaluated. The elderly patient group included patients over 50 years old, whereas the young patient group included patients between 20 and 30 years of age. Eighty-nine patients were included in the elderly patient group, and 51 were included in the young patient group.

The patients who had lost all premolar and molar teeth were considered as the posterior edentulous patient group in the elderly group. As the number of patients who had no missing premolar and molar was insufficient, the patients who had only one or two posterior teeth missing were categorised as the posterior dentate group in the elderly group. Among the elderly patient group, 48 of the patients were included in the posterior dentate group and 41 were included in the posterior edentulous group.

The young patient group consisted of patients who had all their premolars and molars and $51 \mathrm{pa}-$ tients were included in this group.

The CBCT images of the patients who had undergone alveolar crest implantation and bone grafting close to the maxillary sinus, the patients who had extensive pathologies disturbing the anatomy of the working field such as tumours or cysts, and the pa- tients with syndromes or disorders affecting bone metabolism were not included in the study.

\section{$\mathrm{CBCT}$ image acquisition and analysis}

The images obtained by NewTom 5G (Verona, Italy) $C B C T$ machine, using cone beam technique and $110 \mathrm{kVp}$ and with maximum $20 \mathrm{~mA}$ as standards, were evaluated. The patients were in a supine position during $\mathrm{CBCT}$ imaging. The duration of imaging was $18 \mathrm{~s}$. Images with a field of view of $18 \times 16$ or $15 \times 12$ centimetre were used. The voxel values of the images were $0.3,0.25$, and $0.2 \mathrm{~mm}$.

The CBCT images were evaluated by an experienced oral radiologist using NNT (New NewTom, Verona, Italy) software. Among the multiplanar reformation images, the coronal sections were particularly examined, and the presence of any pathology, septation, accessory ostium, and Haller cell was recorded for each sinus. The results were categorised and evaluated according to the elderly patient (posterior edentulous + dentate) and young patient groups.

\section{Definition of maxillary sinus pathologies and anatomical variations}

The dome-shaped opacities located within the maxillary sinus were considered as retention cysts [10], and the mucosal thickenings over $3 \mathrm{~mm}$ [21] and the polypoid lesions originating from the sinus mucosa [11], which were in a size that did not prevent seeing anatomical variations, were considered as pathological. The sinus pathologies such as retention cysts (Fig. 1A), mucosal thickening over $3 \mathrm{~mm}$ (Fig. 1B) and polypoid lesion (Fig. 1C) were shown in Figure 1. The records of patients who had extensive inflammatory lesions such as polyps or opacifications large enough to alter sinus anatomy were not included in the study.

The cortical bone process extending from the lateral or inferior sinus wall into the sinus was considered as a septum [5]. The extra ostium located in the medial sinus wall, in addition to the natural ostium, was considered as an accessory ostium [8]. The cell that develops medial to the roof of the maxillary sinus and medial to the inferior wall of the orbit was considered as the Haller cell [6]. The maxillary sinus anatomical variations as septa (Fig. 2A), accessory ostium (Fig. 2B) and Haller cell (Fig. 2C) were shown in Figure 2.

\section{Statistical analysis}

The data were analysed using Statistical Package for Social Sciences (SPSS), version 20.0. Chi-square 


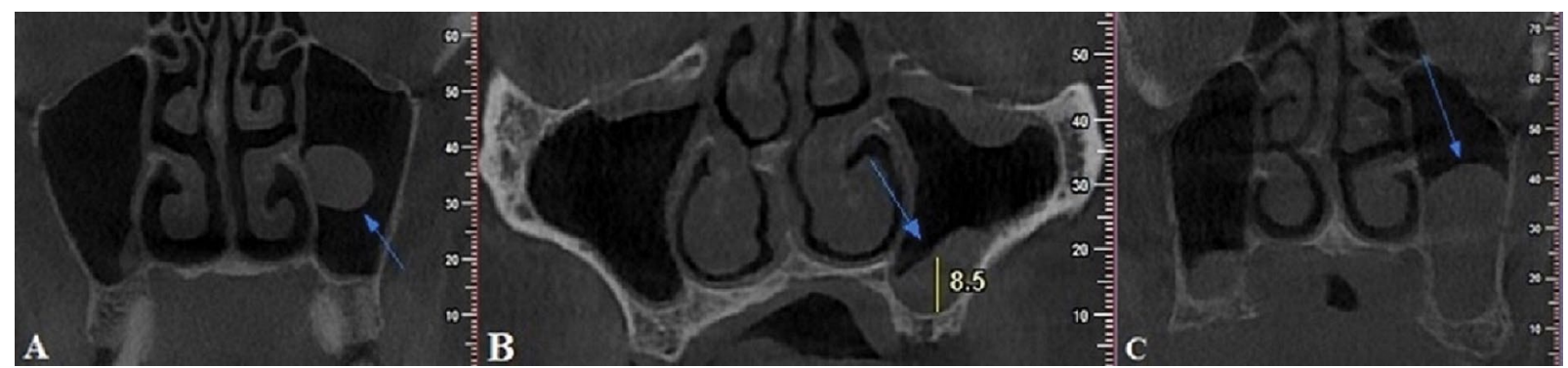

Figure 1. Coronal cone-beam computed tomography images show maxillary sinus pathologies with arrow; A. Retention cyst; B. Mucosal thickenings over $3 \mathrm{~mm}$; C. Polypoid lesion.

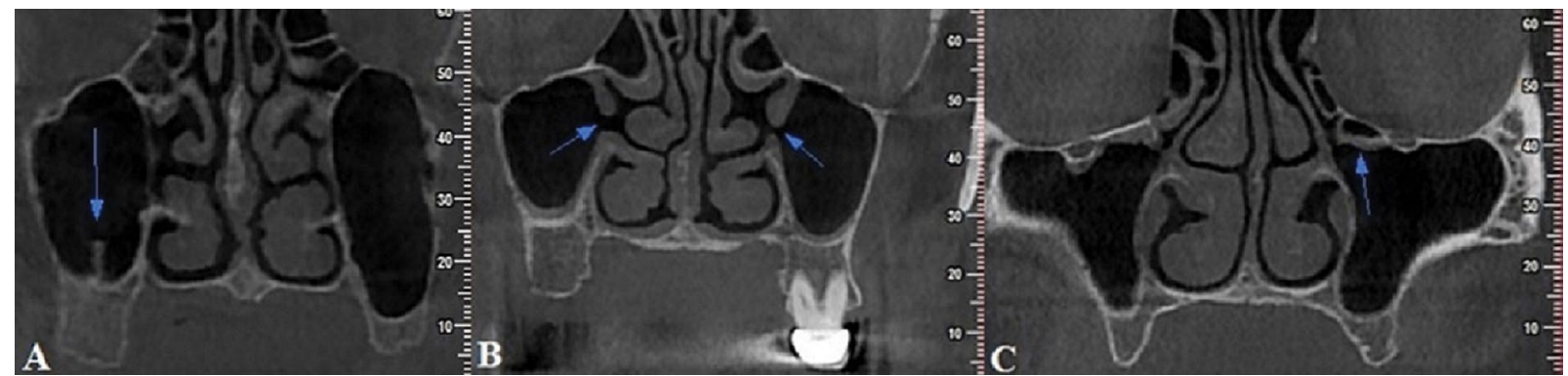

Figure 2. Coronal cone-beam computed tomography images show maxillary sinus anatomical variations with arrow; A. Septa; B. Maxillary accessory ostium; C. Haller cell.

test was used to determine the differences between the groups $(p<0.05)$.

\section{RESULTS}

Cone-beam computed tomography results of 258 maxillary sinuses from 140 patients were evaluated. For all the patients included in the study, the age range was 20-79 years with a mean age of $45.17 \pm$ \pm 18 years. For the elderly group, the age range was $50-79$ years with a mean age of $58.42 \pm 7.21$ years (partial dentate group age range: $50-76$, mean: $56.78 \pm$ \pm 5.77 , posterior edentulous group age range $50-79$, mean $60.08 \pm 8.12$ ). The age range for young patient group was $20-28$ years, and the mean age was $23.21 \pm$ \pm 2.09 years (Table 1 ).

Among the elderly patient group, 163 maxillary sinuses of 89 patients were evaluated. In the partial dentate sub-group of elderly patient group, a total of 82 maxillary sinuses of 48 patients were evaluated. In the posterior edentulous sub-group of elderly patient group, a total of 81 maxillary sinuses of 41 patients were evaluated. For the young patient group, a total of 95 maxillary sinuses from 51 patients were evaluated. The distribution of evaluated maxillary sinus according to gender and groups is presented in Table 2 .

The frequency and statistical differences in pathologies and anatomical variations between the groups are shown in the Tables 3 and 4.
Table 1. Distribution of evaluated patients' age range and mean age according to groups

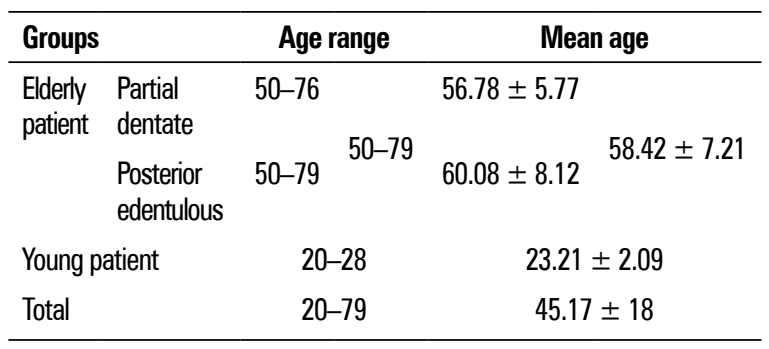

Table 2. Distribution of evaluated maxillary sinus and patients according to groups and gender

\begin{tabular}{llccc}
\hline \multicolumn{1}{l}{ Groups } & Gender & Patient & Maxillary sinus \\
\hline Elderly & Partial & Female & $30(21.43 \%)$ & $48(18.6 \%)$ \\
patient & dentate & Male & $18(12.85 \%)$ & $34(13.17 \%)$ \\
& Posterior & Female & $17(12.15 \%)$ & $34(13.17 \%)$ \\
\multicolumn{1}{c}{ edentulous } & Male & $24(17.14 \%)$ & $47(18.22 \%)$ \\
Young patient & Female & $27(19.29 \%)$ & $50(16.38 \%)$ \\
& Male & $24(17.14 \%)$ & $45(17.44 \%)$ \\
Total & & $140(100 \%)$ & $258(100 \%)$ \\
\hline
\end{tabular}

\section{DISCUSSION}

The anatomical structure of the maxillary sinus is crucial for dentistry [10]. The findings related to inflammation of the maxillary sinus are important for the sinus lift procedure. This problem is associated with the 
Table 3. Comparison of the frequency of maxillary sinus pathology and anatomical variations in between elderly patients and young patient; ${ }^{*} p<0.05$, chi-square test

\begin{tabular}{lcccc}
\hline $\begin{array}{l}\text { Evaluated pathol- } \\
\text { ogy and anatomi- } \\
\text { cal variations }\end{array}$ & $\begin{array}{c}\text { Elderly } \\
\text { patient } \\
\text { group }\end{array}$ & $\begin{array}{c}\text { Young } \\
\text { patient } \\
\text { group }\end{array}$ & Total & $\begin{array}{c}\text { Chi-square } \\
\text { test } \\
\text { Pr }\end{array}$ \\
\hline Pathology & $75(46 \%)$ & $33(34.7 \%)$ & $108(41.9 \%)$ & 0.077 \\
Septa & $46(28.2 \%)$ & $22(23.2 \%)$ & $68(26.4 \%)$ & 0.37 \\
Accessory ostium & $73(44.8 \%)$ & $27(28.4 \%)$ & $100(38.8 \%)$ & $\mathbf{0 . 0 0 9 *}$ \\
Haller cell & $13(8 \%)$ & $24(25.3 \%)$ & $37(14.3 \%)$ & $\mathbf{0 . 0 0 0 *}$ \\
\hline
\end{tabular}

Table 4. Comparison of the frequency of maxillary sinus pathology and anatomical variations in between posterior dentate patients and posterior edentulous patients in the elderly patients group. ${ }^{*} p<0.05$, chi-square test

\begin{tabular}{lcccc}
\hline $\begin{array}{l}\text { Evaluated } \\
\text { pathology and } \\
\text { anatomical } \\
\text { variations }\end{array}$ & $\begin{array}{c}\text { Posterior } \\
\text { dentate } \\
\text { patient } \\
\text { group }\end{array}$ & $\begin{array}{c}\text { Posterior } \\
\text { edentulous } \\
\text { patient } \\
\text { group }\end{array}$ & $\begin{array}{c}\text { Total in } \\
\text { elderly } \\
\text { patients } \\
\text { group }\end{array}$ & $\begin{array}{c}\text { Chi- } \\
\text {-square } \\
\text { test } \\
\text { P }\end{array}$ \\
\hline Pathology & $35(42.7 \%)$ & $40(49.4 \%)$ & $75(46 \%)$ & 0.39 \\
Septa & $22(26.8 \%)$ & $24(29.6 \%)$ & $46(28.2 \%)$ & 0.69 \\
Accessory ostium & $29(35.4 \%)$ & $44(54.35 \%)$ & $73(44.8 \%)$ & $\mathbf{0 . 0 1 5 *}$ \\
Haller cell & $6(7.3 \%)$ & $7(8.65 \%)$ & $13(8 \%)$ & 0.75 \\
\hline
\end{tabular}

pathologies and anatomical variations of the maxillary sinus [23]. CBCT, a significant imaging technique in dentistry, is considered fundamental for detection of maxillary sinus lesions and anatomical variations [10].

According to Som [17], sinus mucosa thickening does not occur under normal conditions. More than $3 \mathrm{~mm}$ thickening of the mucosa is considered as pathological [21]. The polypoid lesions in the maxillary sinus are known as mucous retention cysts and antrochoanal polyps [10]. The mucous retention cysts are the domeshaped opacities in the maxillary sinus walls, which form because of the clogged mucous glands [10]. Antrochoanal polyps are benign polypoid lesions originating from the sinus mucosa [11]. In their study, which was performed using CBCT, Ritter et al. [14] found the total prevalence of maxillary sinus pathologies to be $56 \%$, and that the frequency of pathology was statistically significantly higher in the group aged over 60 years. In our study, mucosal thickenings over $3 \mathrm{~mm}$, retention cysts, and polypoid lesions were considered as pathological finding. The pathology frequency was not statistically significant between the all groups evaluated in this study.

Presence of septa in the maxillary sinus increases the risk of membrane perforation in sinus floor elevation procedures [20]. Such a perforation can result in acute or chronic sinusitis and can lead to bone resorp- tion [1]. Mudgade et al. [7] found the prevalence of septa to be $66.7 \%$ and Shahidi et al. [16] found to be $45.4 \%$ with CBCT. Qian et al. [12] compared the prevalence of septation among edentulous patients (57.4\%) and dentate patients (39.7\%) using CBCT imaging. They determined that septa prevalence was statistically significantly higher in edentulous patients. Schriber et al. [15] conducted a study on edentulous and dentate patients, whose mean age was 58.3 years. They found no statistically significant difference between the edentulous and dentate areas regarding septa prevalence [15]. In our study, there was not statistically significant difference between the posterior dentate and edentulous groups and between the elderly and young groups regarding the frequency of septa.

Yenigün et al. [22] conducted a study among patients with the mean age of $36.21 \pm 15.50$ years and found that $19 \%$ of their patients had an accessory ostium. The same study also concluded that the formation of these ostia was statistically significantly more common in patients with mucous retention cysts, mucosal thickenings, and maxillary sinusitis [22]. In our study the frequency of accessory maxillary ostium was higher in the elderly patient group than in the young patient group; it was also higher in the posterior edentulous patient group than in the posterior dentate patient group.

Haller cells can cause maxillary sinusitis when they enlarge and subsequently constrict the ostiomeatal complex [18]. Pekiner et al. [9] determined the frequency of Haller cells to be $43 \%$ in the group of subjects with a mean age of 33.24 years and found no statistically significant difference regarding the occurrence of Haller cells among the groups aged 20-29, 30-39, $40-49$, and above 50 years. In our study the frequency of Haller cell was found to be higher in the young patient group compared to the elderly patient group. However there was no statistically significant difference between the posterior dentate and edentulous patient groups regarding the frequency of Haller cell.

\section{CONCLUSIONS}

The prevalence of Haller cells (which can influence sinusitis development) and accessory maxillary ostium were found to be statistically dependent on old age and the absence of teeth. The frequency of accessory ostium was found to increase with age, and this increase was more prominent in total edentulism. In addition to the currently present information in the literature suggesting a relationship between accessory ostium and sinusitis, we determined that old age con- 
tributes to the increased prevalence of maxillary sinus ostium, especially in totally edentulous patients. We suggest that this situation might be related to elderliness and the resorption mechanism that follows total edentulism. It was also determined that the frequency of Haller cells decreased with elderliness; however, this reduction did not correlate with total edentulism. We suggest that further studies, especially concerning Haller cells and accessory maxillary ostium in elderly and edentulous patients, should be performed.

\section{Acknowledgements}

This study was presented as an oral presentation in $13^{\text {th }}$ International ENT (Ear, Nose and Throat) Head and Neck Surgery Congress on 5-7 April 2018 in Turkey Ankara.

\section{REFERENCES}

1. Abrahams JJ, Hayt MW, Rock R. Sinus lift procedure of the maxilla in patients with inadequate bone for dental implants: radiographic appearance. AJR Am J Roentgenol. 2000; 174(5): 1289-1292, doi: 10.2214/ ajr.174.5.1741289, indexed in Pubmed: 10789779.

2. Ali IK, Sansare K, Karjodkar FR, et al. Cone-beam computed tomography analysis of accessory maxillary ostium and Haller cells: Prevalence and clinical significance. Imaging Sci Dent. 2017; 47(1): 33-37, doi: 10.5624/ isd.2017.47.1.33, indexed in Pubmed: 28361027.

3. Dedeoğlu N, Altun O, Bilge O, et al. Evaluation of anatomical variations of nasal cavity and paranasal sinuseswith cone beam computed tomography. Nobel Med. 2017; 13(2): 36-41.

4. Del Fabbro M, Rosano G, Taschieri S. Implant survival rates after maxillary sinus augmentation. Eur J Oral Sci. 2008; 116(6): 497-506, doi: 10.1111/j.1600-0722.2008.00571.x, indexed in Pubmed: 19049518.

5. Maestre-Ferrín L, Galán-Gil S, Rubio-Serrano M, et al. Maxillary sinus septa: a systematic review. Med Oral Patol Oral Cir Bucal. 2010; 15(2): e383-e386, doi: 10.4317/ medoral.15.e383, indexed in Pubmed: 19767706.

6. Mathew R, Omami G, Hand A, et al. Cone beam CT analysis of Haller cells: prevalence and clinical significance. Dentomaxillofac Radiol. 2013; 42(9): 20130055, doi: 10.1259/ dmfr.20130055, indexed in Pubmed: 23975112.

7. Mudgade D, Motghare P, Kunjir G, et al. Prevalence of anatomical variations in maxillary sinus using cone beam computed tomography. J Indian Acad Oral Med Radiol. 2018; 30(1): 18, doi: 10.4103/jiaomr.jiaomr_81_17.

8. Na Y, Kim K, Kim SK, et al. The quantitative effect of an accessory ostium on ventilation of the maxillary sinus. Respir Physiol Neurobiol. 2012; 181(1): 62-73, doi: 10.1016/j. resp.2012.01.013, indexed in Pubmed: 22326723.

9. Pekiner F, Borahan M, Dumlu A, et al. Infraorbital ethmoid (Haller) cells: a cone-beam computed tomographic study. Oral Radiol. 2014; 30(3): 219-225, doi: 10.1007/s11282014-0167-3.

10. Pelinsari Lana J, Moura Moura Rodrigues $P$, de Carvalho Machado V, et al. Anatomic variations and lesions of the maxillary sinus detected in cone beam computed tomography for dental implants. Clin Oral Implants Res. 2012; 23(12): 1398-1403, doi: 10.1111/j.16000501.2011.02321.x, indexed in Pubmed: 22092889.

11. Pruna $X$, Ibañez JM, Serres $X$, et al. Antrochoanal polyps in children: $\mathrm{CT}$ findings and differential diagnosis. Eur Radiol. 2000; 10(5): 849-851, doi: 10.1007/s003300051017, indexed in Pubmed: 10823646.

12. Qian L, Tian Xm, Zeng Li, et al. Analysis of the morphology of maxillary sinus septa on reconstructed cone-beam computed tomography images. J Oral Maxillofac Surg. 2016; 74(4): 729-737, doi: 10.1016/j.joms.2015.11.019, indexed in Pubmed: 26707431.

13. Rege IC, Sousa TO, Leles CR, et al. Occurrence of maxillary sinus abnormalities detected by cone beam CT in asymptomatic patients. BMC Oral Health. 2012; 12: 30, doi: 10.1186/1472-6831-12-30, indexed in Pubmed: 22883529.

14. Ritter L, Lutz J, Neugebauer J, et al. Prevalence of pathologic findings in the maxillary sinus in cone-beam computerized tomography. Oral Surg Oral Med Oral Pathol Oral Radiol Endod. 2011; 111(5): 634-640, doi: 10.1016/j. tripleo.2010.12.007, indexed in Pubmed: 21444226.

15. Schriber M, von Arx T, Sendi $P$, et al. Evaluating maxillary sinus septa using cone beam computed tomography: is there a difference in frequency and type between the dentate and edentulous posterior maxilla? Int J Oral Maxillofac Implants. 2017; 32(6): 1324-1332, doi: 10.11607/ jomi.5854, indexed in Pubmed: 29140376.

16. Shahidi S, Zamiri B, Momeni Danaei S, et al. Evaluation of anatomic variations in maxillary sinus with the aid of cone beam computed tomography (CBCT) in a population in south of Iran. J Dent (Shiraz). 2016; 17(1): 7-15, indexed in Pubmed: 26966702.

17. Som PM. CT of the paranasal sinuses. Neuroradiology. 1985; 27(3): 189-201, doi: 10.1007/bf00344487.

18. Stackpole SA, Edelstein DR. The anatomic relevance of the Haller cell in sinusitis. Am J Rhinol. 1997; 11(3): 219-223, indexed in Pubmed: 9209594.

19. Tan WC, Lang NP, Zwahlen M, et al. A systematic review of the success of sinus floor elevation and survival of implants inserted in combination with sinus floor elevation. Part II: transalveolar technique. J Clin Periodontol. 2008; 35(8 Suppl): 241-254, doi: 10.1111/j.1600-051X.2008.01273.x, indexed in Pubmed: 18724853.

20. Vogiatzi T, Kloukos D, Scarfe WC, et al. Incidence of anatomical variations and disease of the maxillary sinuses as identified by cone beam computed tomography: a systematic review. Int J Oral Maxillofac Implants. 2014; 29(6): 1301-1314, doi: 10.11607/jomi.3644, indexed in Pubmed: 25397794.

21. White SC, Pharoah MJ. Oral Radiology- Principles and Interpretation. 5th Ed. St. Louis: MO Mosby. 2004.

22. Yenigun A, Fazliogullari Z, Gun C, et al. The effect of the presence of the accessory maxillary ostium on the maxillary sinus. Eur Arch Otorhinolaryngol. 2016; 273(12): 4315-4319, doi: 10.1007/s00405-016-4129-8, indexed in Pubmed: 27300297.

23. Zijderveld SA, van den Bergh JPA, Schulten EA, et al. Anatomical and surgical findings and complications in 100 consecutive maxillary sinus floor elevation procedures. J Oral Maxillofac Surg. 2008; 66(7): 1426-1438, doi: 10.1016/j. joms.2008.01.027, indexed in Pubmed: 18571027. 